\title{
Quando a máquina ataca: notas sobre cinema e engajamento
}

\author{
Érico Oliveira de Araújo Lima
}

\section{Introdução: a máquina tem suas táticas}

Destaquemos, primeiro, e assumamos desde já, uma aposta fundamental, contida nas bases deste texto: a de que os dois filmes que tomaremos mais de perto, Nova Dubai (Gustavo Vinagre, 2014) e Branco sai preto fica (Adirley Queirós, 2014) articulam, por modos singulares, o que poderíamos chamar de um cinema engajado. Não se trata aqui de classificar um campo da produção recente de imagens, mas de resgatar, deliberadamente, uma noção que parecia ter ficado caduca no trato com a arte de um modo geral, e com o cinema em particular, que no mais das vezes foi tendo de se formalizar segundo uma estética de sutilezas ou de contenções, que parecia despontar como a solução contemporânea para formular o problema da política. O debate sobre os caminhos de um cinema político é longo, e não cabe aqui retomá-lo em demasia, mas vale reter que os embates de toda uma tradição do cinema moderno ao longo dos anos 1960 e 1970 dizem respeito, sobretudo, às tensões, modulações e passagens que diferentes realizadores operaram no modo de conceber um gesto político por parte da imagem. Se parecia haver, nesses percursos históricos rumo ao nosso tempo, uma progressiva resolução a respeito de uma quase rejeição a noções de um cinema militante, ou da nomeação de um cinema engajado, a história das formas revela-se, mais uma vez, marcada por variações e retornos de estratégias. É como se certos gestos imagéticos voltassem a habitar, em diferença, a cena do presente, ressoando a urgência do embate e do engajamento com o mundo ${ }^{1}$.

Eis, então, como nos parecem despontar os gestos de Branco sai preto fica e Nova Dubai. Eles não estão sozinhos. Eles também não se reúnem a outros gestos, numa absoluta

1 Nossa aposta em resgatar esses termos de um cinema engajado vem na esteira de alguns pensamentos que nos mobilizam, como as discussões recentes trazidas por Nicole Brenez, que retoma, inclusive, a noção de panfleto para abordar algumas imagens contemporâneas, e também as discussões de Amaranta César, que muito tem se dedicado a pensar formas militantes de cinema e a imagem como ato de engajamento. 
indiferenciação, subsumidos a uma pretensa nova categoria. Mas compõem, a nosso ver, a emergência de uma cena repleta de singularidades, na qual são experimentadas novas tonalidades para pensar o cinema brasileiro recente segundo a chave do engajamento. Tomamos esses dois filmes com um interesse efetivo em ter atenção a suas formas singulares, mas queremos também tornar pensável um campo mais amplo de táticas pelas quais o cinema pode afetar o real e tensionar os esquadrinhamentos dos territórios e as gestões de nossa vida coletiva, recompondo, assim, outras possibilidades de vida em comum. Temos, portanto, essa escala, os próprios filmes, mas também uma moldura, os múltiplos intercâmbios entre imagem e engajamento no mundo vivido.

Partamos para o corpo fílmico, efetivamente. Na sequência que faz uma explosão sonora precipitar-se em Brasília, ao final de Branco sai preto fica (Adirley Queirós, 2014), um aspecto fundamental precisa ser considerado muito de perto: a vingança que se tramou ao longo de todo o filme é efetivada em traços de um desenho feito por Sartana (Shokito), um dos personagens dessa deriva ficcional atravessada pela experiência vivida de uma comunidade na Ceilândia. Esse desencadear em clímax do plano arquitetado se dá com um apelo visual que ressalta a própria dimensão de fabricação do ataque cinematográfico. Ou se pudermos dizer em outros termos, nessa sequência final, papel, lápis e desenho articulam a evidência do cinema como artifício, da bomba que se produziu como artifício pelo e no cinema. E igualmente importante, esse trabalho de forjar a insurgência de uma comunidade não se dá a despeito dos sujeitos em cena, mas justo numa relação entre o corpo do filme e os corpos dos personagens, porque os desenhos que emergem para ocupar todo o quadro já vinham sendo produzidos por Sartana durante todo o curso do filme, como ressalta a montagem em muitos instantes do decorrer da projeção. A tessitura mesma do filme enfatiza que uma comunidade pelo e no cinema se dá na medida de um duplo trabalho da cena: ela se arranja por meio das figuras inventadas na dramaturgia e na montagem - na trama de uma máquina-cinema -, mas está também intimamente vinculada às experiências de corpos dos sujeitos filmados, tanto ao que eles podem fabricar e projetar no mundo quanto àquilo que ficou incrustado na pele. Isso quer dizer que também os corpos dos atores que entram em cena se engajam na produção maquínica das suas subjetividades.

O cinema dispara, então, um conjunto de processos produtores que não cessam de se reenviar uns aos outros, ao mesmo tempo em que fincam um pé muito forte no real. Pois é preciso dizer que esse filme de Adirley Queirós se articula a partir da experiência 
vivida por Marquim e Sartana, em 5 de março de 1986, na Ceilândia, quando a polícia invadiu o baile do Quarentão e atropelou os corpos que estavam em festa. Dizendo em linhas gerais o próprio enredo do filme: Branco sai preto fica toma, portanto, um acontecimento histórico na Ceilândia, uma cidade-satélite de Brasília, capital federal do Brasil, para elaborar uma trama ficcional entremeada com testemunhos e com a experiência vivida. Estamos juntos aos percursos dos dois homens que viveram uma repressão policial nos anos 1980 e seguimos com eles para a elaboração de um plano de explosão sonora do centro do poder, Brasília. Paralelamente, acompanhamos ainda a trajetória de um viajante do tempo, Dimas Cravalanças, que tem a missão de vir do futuro para investigar os crimes cometidos pelo Estado contra as populações negras e periféricas.

Fundamental aqui é que essa repressão é direcionada e seletiva, como anuncia o título do filme, recuperado no testemunho performado por Marquim logo na abertura. Trata-se de um racismo institucional e de Estado que abre fenda na história do Brasil, um racismo que marca nossa experiência histórica e constitui as relações desiguais, excludentes e hierárquicas, permeadas por políticas de extermínio nas periferias. Branco sai preto fica: eis a demarcação que os poderes impõem e que se materializa nas ações da polícia. O trauma do passado é reinventado pelas memórias e será o mote do trabalho produtor da insurgência sonora, que coleta uma matéria ressonante da Ceilândia, para vingar - para fazer sobreviver - uma geração de amputados. Se todas essas operações passam ao mundo fílmico, nosso interesse é, então, o de indagar, mais precisamente, sobre como pode o cinema dar forma a esse desejo de insurgência, pela mobilização de um conjunto de recursos expressivos do campo da ficção, a penetrar um ponto de partida documental. É preciso, então, se perguntar por aquilo que se constitui filmicamente na máquina, quando os sujeitos se põem a fabular no limiar entre o vivido e o narrado, entre o vivido e o imaginado. A operação de Branco sai preto fica faz do trabalho da ficção e do artifício uma arma para embaralhar uma cena vivida, uma repartição de competências e de possibilidades, um esquadrinhamento de territórios, uma imposição policial dos poderes para os modos de vida em comunidade. Nesse jogo de tensão com essa ordenação articulada no campo do real, o cinema pode, em alguma medida, interpor uma nova cena, que dobre a configuração da polis, para fazer surgir, na própria tessitura fílmica, uma comunidade inédita, aparição singular de uma modalidade inaudita de estar junto. É como se o cinema pudesse, então, ser um reenvio ao mundo, uma forma de retorno que possa engajar-se no presente e tornar sensíveis outras formas de vida. 
Chegamos aqui a outro ponto que será fundamental para as indagações que aqui tentamos movimentar. Já destacamos o corpo dos personagens em cena e também enfatizamos a importância de acompanhar de perto o trabalho da escritura - o corpo fílmico -, mas resta completar um circuito. Se falamos de engajamento, é preciso considerar que o cinema engaja ainda um terceiro corpo, aquele do espectador, que se põe a trabalhar e a perscrutar as imagens e os sons, num jogo de ressonâncias afetivas entre a poética da obra, sua fabricação, e a apreensão sensível, seu modo de afetação. Corpo sobre corpo, essa tripla relação corpórea nos permite pensar as estratégias fílmicas em termos de uma conexão entre cinema e mundo, que não se dá simplesmente por adesão, mas por uma série de fricções que talvez sejam justo o mote para possíveis engajamentos. Podemos encontrar nessa chave fundamental das relações corpóreas um modo de experiência sensível que diga de uma política das formas, a saber, de como as manipulações dos artifícios, dos quadros, das escalas, dos blocos de espaço e de tempo, no campo do cinema, concernem às circunstâncias de corpo, de sensibilidade e de vida social de uma comunidade de espectadores. E então aqui o problema da poiesis da imagem traça uma ponte irrevogável com um fora da imagem - ou talvez seria mesmo preciso dizer melhor: se temos esse circuito corpóreo por horizonte de análise, talvez possamos pensar na máquina-cinema como algo intrinsecamente relacional, capaz mesmo de complicar a separação entre dentro e fora. A fabricação de uma imagem, digamos assim, tem a ver, de imediato, com uma implicação do outro, com a busca por manejos das formas, para engajar afetivamente o espectador.

Traçando uma outra estratégia de intercâmbio entre o real e o artifício, mas também com um forte empenho em pesquisar formas de engajamento, Nova Dubai (Gustavo Vinagre, 2014) inventa figuras singulares de mise-en-scène e montagem para operar perturbações em outra cena urbana, a de uma cidade em que a construção de arranha-céus desfaz modalidades de experiência afetiva de alguns jovens de classe média. $\mathrm{O}$ filme se concentra nas vizinhanças do bairro Jardim Alvorada, em São José dos Campos, município do interior de São Paulo que passa a ser invadido por imensos prédios, dentro de uma reforma urbana tão cara a muitas cidades brasileiras. O próprio realizador, Gustavo Vinagre, se coloca em cena com amigos, que têm como uma das ações mais emblemáticas a performance do sexo em espaços públicos. Diante da destruição do espaço afetivo pelas políticas do Estado e do mercado, o desenrolar do filme se estrutura em um conjunto de práticas de apropriação corporal do urbano, em meio a essa paisagem que se reconfigura - 
cenas de sexo ao ar livre, alternadas com conversas no interior das casas, a respeito da morte, dos amores, das relações familiares, da memória.

Para além de uma resposta nostálgica que tentaria resgatar um sentimento perdido, o filme parte para um confronto direto, que agora passa pela expressão dos desejos dos corpos na cidade. Se Marquim e Sartana respondiam com uma bomba sonora, somos dessa vez colocados diante de outra modalidade de inscrição da insurgência na cena e, particularmente, de uma outra via traçada entre o real e as formas de artifício possibilitadas pelo artefato cinematográfico. Em uma das sequências, um operário de construção civil dá uma entrevista para os jovens, relatando experiências sexuais, segundo uma forma de enquadramento e de disposição cênica que emulam as estratégias de uma entrevista do campo do documentário clássico. Logo em seguida, somos jogados para uma performance sexual entre o sujeito filmado no plano anterior e os dois jovens que o entrevistavam. A relação entre quem filma e quem é filmado se transforma radicalmente para um contágio efetivamente carnal. O registro de uma falsa entrevista documental, desmontada na própria escritura, cristaliza um domínio discursivo tipicamente ligado ao real, que é aqui enrabado. Existe uma espécie de contrabando de uma discursividade mais tradicionalmente ligada à noção de real para uma trama intricada de artifícios, fazendo irromper, na tessitura da ficção, um estranho e desviante efeito de real, que passa a integrar o jogo estratégico para o engajamento afetivo do espectador. O empenho do corpo no ato de ver e ouvir ganha novas camadas, dentro da linha que tentaremos traçar, ao se deparar com essa outra via de manipulação dos recursos da máquina-cinema. Os embates entre filme e mundo, a partir da singularidade desse processo instaurado por Nova Dubai, colocam novos problemas para a tarefa de pensar a constituição de engajamentos a partir das infiltrações entre experiências vividas e as formas expressivas do cinema.

Nossa busca aqui será, então, a de perscrutar os procedimentos singulares desses dois filmes, para indagar a respeito dos modos pelos quais a cena cinematográfica pode se transformar em uma condensação de contrabandos de mão dupla, entre os domínios do real e os do artifício, organizados em um gesto que se empenha em reconfigurar territórios, pela criação de experiências sensíveis de aberto combate, e arriscaríamos chamá-las mesmo de terroristas, como tentaremos desenvolver. Trata-se de saber, por um lado, em que medida o cinema pode engajar-se no presente e nas experiências vividas e, por outro, de como ele pode suscitar engajamentos afetivos por parte do espectador. Mais amplamente, nosso impulso de pensamento, nesse cotejamento exploratório, diz respeito a 
um interesse mais alargado em saber como pode o cinema produzir novos modos de vida em comum. E essa questão, para ser enfrentada, precisa passar pela investigação de como pode ser engajada uma comunidade de espectadores, na práxis social mesma de ver filmes que se colocam a produzir outros conhecimentos e sensações de mundo.

\section{Engajar corpo sobre corpo}

Seria importante fazer um breve recuo para sublinhar um terreno de base que instaura a circunstância de um vocabulário. E é preciso sublinhar essa expressão, "circunstância de um vocabulário", porque nos interessa menos uma discussão exaustiva em torno de conceitos formulados a priori, para simplesmente aplicá-los aos filmes, do que uma aproximação junto à cena de pensamento que esses conceitos fabricam e às formulações de problemas que eles possibilitam, para então nos encaminharmos às especificidades das formas fílmicas que analisamos e às interrogações singulares que elas nos fazem. Trata-se, em certa medida, de um vocabulário que projeta certo gesto de operação, uma visada de método, numa íntima implicação entre o teórico e o metodológico.

Tentemos, então, precisar um pouco mais de que se trata essa perspectiva engajada que reivindicamos para esse cinema. Temos aqui um circuito triplo, como já sugerimos acima, que envolve corpos em cena, corpo fílmico e corpo do espectador. Esses corpos, que não são todos de uma mesma natureza nem são apenas da ordem do humano, operam entre si um íntimo agenciamento, desencadeando, um engendramento que é, em realidade, inseparável. É, então, apenas provisoriamente, que vamos fragmentar dois momentos dessa interação, para fins de uma aproximação mais detida nas questões convocadas por cada um desses eixos de relação.

Primeiro eixo, portanto: falar em engajamento diz respeito ao modo como um filme tece relação com aquilo que do mundo vivido pode se precipitar na cena, ainda que haja todo o trabalho de mediação e de reelaboração efetuados por dramaturgia e montagem por um aparato cinematográfico, enfim. A questão é pensar como a máquina se engaja no real, no tempo histórico, nas experiências do mundo filmado, não simplesmente para retornar ao espectador uma verdade dessa matéria, e daí propor uma pronta tomada de consciência, mas para fazer essa matéria variar, para performá-la. Justo na exposição 
disparada pela cena, algo do mundo se reordena, se desorganiza. Cabe pensar que estamos falando aqui do trabalho de um corpo, o próprio corpo fílmico, em todas as suas operações expressivas, como um ser que age nesse mundo filmado, para instaurar nele outras cenas. Como diz Cezar Migliorin (2011), ao tratar de figuras do engajamento no cinema brasileiro recente, é fundamental guardar a dimensão de um gesto que entra no que dura e, portanto, se insere na própria variação do presente: não um presente como momento ordenador de um passado e de um futuro, mas um presente de intensidades.

Poderíamos afirmar que só existe engajamento no presente. É na ordem de um engajamento entre um mundo vivido, histórico, sofrido e um mundo desejado, atuado e performado, que atravessa um encontro entre quem filma e quem é filmado, que a inscrição cinematográfica pode ser levada a uma sala de cinema, oferecida a um público. $\mathrm{O}$ engajamento nas artes só existe no presente como tensão entre história, memória e mundo transformado, variado com as forças e redes que são colocadas em ação no presente. Na máquina-cinema, o engajamento é um agir com múltiplos tempos na variação do presente. Um agir com múltiplas forças nas forças do presente (MIGLIORIN, 2011, p.17).

Há algo de um sofrimento no mundo vivido, de um pathos, ou de um conjunto de restrições que se afiguram para as experiências, a todo instante em vias de constituir um mundo desejado e performado. Essa tensão fundamental indicada por Migliorin diz respeito a um primeiro acesso à noção de formas de engajamento que gostaríamos de salientar, na escritura mesma dos filmes de Adirley Queirós e de Gustavo Vinagre. Se existem, como já pontuamos, diferenças de métodos entre os dois, há também distinções nas vidas sociais que se tornam matéria para as fabricações levadas adiante pelos dois. Essas diferenças entre os contextos de cada filme marcam também modos de se engajar que são particulares a cada cena. Falemos, então, primeiro, do que está em jogo quando consideramos os engajamentos de cada filme nas experiências históricas que lhes acercam.

O território que se anuncia como zona de conflito, em Branco sai preto fica, tem uma configuração bastante específica, porque estamos diante dos embates de uma periferia negra, situada na Ceilândia, em radical conflito com os modos de ordenação do espaço irradiados do centro, figurado aqui por Brasília. Esse mundo vivido, no qual o filme se engaja, diz respeito, a uma disputa fundamental que deve complicar a separação entre centro e periferia e colocar em contenda o modo pelo qual o Estado projeta as cidades, demarca as identidades, os lugares, as funções. Aqui o cinema vem se fazer, dizendo muito concretamente, lá onde há pobres e negros invisibilizados e atropelados pelos 
poderes, lá onde há um desejo de povos a adquirir uma potência própria de aparição na cena sensível da política. Esses povos estão, no mundo vivido e em nosso tempo histórico, expostos constantemente a um desaparecimento - seja na sua visibilidade, seja na concretude mesma de seu corpo todo. Branco sai preto fica, como veremos mais detidamente adiante, nos propõe táticas cinematográficas de reapropriação dos códigos da ficção - sobretudo da ficção científica - para reelaborar a experiência histórica real do trauma sofrido por sujeitos sociais da Ceilândia, constituindo no cinema uma resposta engajada diante das práticas dos poderes em controlar as populações, em segregar os indivíduos, em mutilar os corpos: toda uma resposta, poderíamos dizer, de uma potência do cinema e dos corpos contra o biopoder gerido pelo Estado, para nos apropriarmos aqui de termos foucaultianos ${ }^{2}$.

Em Nova Dubai, a realidade histórica que ronda a escritura é a mesma bastante recorrente em muitas cidades e filmes brasileiros. Ela pode ser traduzida pela fórmula da "especulação imobiliária", paradigma que abarcaria uma gama de trabalhos realizados em anos recentes, mas aqui vale perceber o quanto esse motivo temático mais imediato está atravessado por múltiplas camadas, que precisam ser detectadas no exame coengendrado entre a cena do filme e a cena do mundo. Porque a grande singularidade do gesto de Vinagre talvez esteja justo no jogo complexo que ele traça entre desejo, imaginário e um mundo no qual os horizontes parecem se fechar, por conta da própria escalada dos prédios na paisagem. A expressão dos corpos na cena, em performances sexuais, torna-se um dos elementos do combate, travado no espaço público, entre o cinema e o mundo. Mas essa forma muito inédita de cinema engajado, que apostamos encontrar em Nova Dubai, se desprende completamente do registro realista e passa a tomar o real com muitas suspeitas, justo como um modo que deve ser, ele mesmo, reelaborado em uma atitude anárquica e iconoclasta com o próprio cinema.

Se ressaltamos essas especificidades contextuais de cada filme, é porque nos interessará, exatamente, o que eles promovem numa cena social e política configurada. A noção de máquina que empregamos aqui nos ajuda a insistir no trabalho de variação e defasagem criado pelo cinema, para afastar uma ideia de continuidade imediata entre imagem e mundo. Na esteira dos escritos de Jean-Louis Commoli (2012), essa seria uma primeira questão fundamental que nos chega de um termo recorrente em seus textos: a

2 A esse respeito, permito-me remeter à seguinte referência, na qual essas questões encontram-se mais desdobradas: FURTADO, Beatriz; LIMA, Érico. Corpo, destruição e potência em Branco sai, preto fica. Revista Matrizes, v.10, no 1, jan./abr. São Paulo, Brasil, 2016. 
máquina-cinema está constantemente sofrendo o real, mas ao filmar o mundo, ela também o transforma. “O mundo 'tal qual é' não é jamais o mundo tal qual queremos que ele seja. Trata-se, então, de mudá-lo enquanto o filmamos, adicionando às realidades essa dose de cinema que as transformam, fazendo passar do estado da constatação ao da questão, de um dado já-aí ao de um dado do possível" (COMOLLI, 2012, p.38). Assim, parece-nos que pensar uma noção de engajamento em termos de imagem demanda, constantemente, olhar para os filmes tendo por horizonte essa dupla operação que é tão cara ao cinema, na relação com o vivido: há uma ligação íntima com o real e com o tempo histórico, mas também a consciência de que, quando esse real atravessa as grades do cinema, ele será devolvido ao mundo em novos termos, justo com o intuito de tornar possíveis outros modos de habitar esse mesmo mundo filmado. Dialogando mais uma vez com Migliorin (2015), cabe sempre interrogar "como a máquina cinema tensiona outras máquinas que atravessam processos subjetivos, políticos e de grupo, ou seja, como a existência do cinema em uma comunidade afeta a própria comunidade, não porque narra isso ou aquilo, mas porque há uma forma de o cinema mobilizar o real que afeta o próprio real" (MIGLIORIN, 2015, p.185).

Isso suscita agora o nosso outro eixo de construção do vocabulário sobre engajamento, que passa justo a uma ênfase naquilo que concerne aos modos pelos quais a forma do filme pode afetar o espectador. E aqui precisamos desdobrar melhor em que consiste trazer o afeto como operador conceitual que coabita a noção de engajamento. Esse aporte é inspirado por um modo como uma matriz de pensamento dos estudos de cinema vem enfatizando a potência da imagem em se efetuar como um corpo, e não como pura representação, sensível etéreo e de simulacro, mas como concretude corpórea, que se implica na comunidade dos viventes e gera um circuito de intercâmbios com um conjunto de matérias heterogêneas. Como nos diz Mariana Baltar (2013), a ideia de afeto diz respeito a "um movimento que se tece no âmbito do fílmico em direção à mobilização das sensações do espectador. Tal movimento se dá como uma expressão que se ampara no corpo e para o corpo, contudo, um corpo que ultrapassa o desejo de representação, mas que se sustenta na performance" (BALTAR, 2013, p.70). Então, temos no afeto uma força capaz de articular uma entrada no universo fílmico, enfatizada menos pelo paradigma representacional que no seu caráter de performance, conceito que Elena Del Río (2008) trabalha numa vinculação muito próxima ao campo de pensamento de Deleuze e Guattari, ao destacarem os processos de invenção e de acontecimento. A performance investe-se de um caráter de emergência: ela é a exposição do corpo, a instauração de uma cena inédita, 
no seu caráter mesmo de criação, fazendo um corte em qualquer mundo já dado ou préconcebido (DEL RÍO, 2008, p.4).

Indo mais diretamente a essa matriz de pensamento de Deleuze e Guattari, central para as formulações de Del Río, podemos sublinhar a estreita ligação que os conceitos de desejo, afeto e corpo guardam com a ideia de máquina. A máquina produz, devemos enfatizar. Para aquilo que nos interessa mais de perto, é importante salientar que a máquina não se confunde, simplesmente, com aspectos técnicos ou mecânicos, ela é uma chave constituinte do pensamento filosófico desses autores para pensar os processos de produção de subjetividade, em estreito agenciamento com múltiplas forças a atravessar o social, o desejo, o humano e o não-humano. A máquina é uma saída operatória frente à noção de estrutura e também diante de uma compreensão de sujeito mais marcada por operadores de fixidez. A produção subjetiva ocorre, assim, no agenciamento com afetos pré-individuais e com forças heterogêneas que conectam o sujeito a elementos de naturezas diferentes. Uma máxima fundamental em $O$ anti-Édipo consiste em buscar a coexistência entre produção social e produção desejante, a partir de um afastamento de qualquer concepção idealista de desejo - marcada, segundo eles, pela falta - e investindo numa abordagem material: "Se o desejo produz, ele produz real. Se o desejo é produtor, ele só pode sê-lo na realidade, e de realidade. [...] O desejo e o seu objeto constituem uma só e mesma coisa: a máquina, enquanto máquina de máquina" (DELEUZE e GUATTARI, 2010, p.43).

Com essa chave operatória da máquina, acreditamos nos aproximar aqui de uma abordagem que privilegia uma integração complexa entre forças heterogêneas - subjetivas e de grupo, históricas, econômicas e sociais, coletivas e individuais, humanas e nãohumanas - e nos afasta um tanto de uma consideração mais marcada pela representação, pelo peso excessivo na intencionalidade de realizadores, pela identidade ou pela biografia de sujeitos. Aqui as consequências analíticas são extraídas de um corpo fílmico, atravessado por múltiplas agências: é o filme mesmo que opera no mundo e no espectador, como máquina-cinema. E se estamos, especialmente, interessados na perturbação que os filmes podem fazer no mundo vivido, a concepção maquínica do desejo e do social nos reenvia ao desarranjo tão caro à produção desejante, sempre a introduzir novas variáveis na produção social, como dizem Deleuze e Guattari, mais uma vez: 
As máquinas desejantes não param de se desarranjar enquanto funcionam, e só funcionam desarranjadas: o produzir se enxerta sempre no produto, e as peças da máquina são também o combustível. A arte utiliza frequentemente essa propriedade, criando verdadeiros fantasmas de grupo que curto-circuitam a produção social com uma produção desejante, e introduzem uma função de desarranjo na reprodução de máquinas técnicas (DELEUZE e GUATTARI, 2010, p.49).

O desarranjo está, portanto, no cerne das máquinas desejantes. "Mais ainda: a própria obra de arte é uma máquina desejante. $\mathrm{O}$ artista acumula o seu tesouro para uma explosão próxima, razão pela qual ele acha que as destruições, na verdade, não advêm com suficiente rapidez" (idem, p.50). E se pensarmos em termos de acontecimentos de imagem, retomando Del Río, podemos falar de singulares modalidades de aparição de uma imagem, engajada tanto no mundo, para reconfigurá-lo, quanto junto ao corpo do outro, para atravessá-lo e desorganizá-lo, também enquanto um corpo que instaura a experiência de alteridade. Afeto é poder de corpo sobre corpo, poderíamos dizer. Trata-se de enfatizar um acontecimento expressivo-afetivo que desencadeia potências de agir (DEL RÍO, 2008, p.8) - e aqui estamos muito próximos de Spinoza, nas formulações de sua Ética, central para essa visada teórica que destacamos a respeito do afeto. Ainda nessa linha, o afeto precisa ser considerado para além de toda pessoalidade, não sendo uma centralidade do humano ou do indivíduo, mas se relacionando a um campo das forças, energias e agenciamentos.

A inflexão dada para a expressão de um corpo como potência se investe aqui de uma concepção ética e, diríamos também, política, para falar de um engajamento afetivo. As potências do corpo criam uma zona de virtualidades, que podem fazer frente às relações de poder da vida social, concebidas no seu caráter de dominância e de paralisação. A potência abre o corpo ao impensado do próprio corpo, ao que ainda pode se efetuar no jogo aberto de um sensível, sentido não dado, ainda por se sentir. Traríamos aqui uma formulação de Del Río que nos parece central para esse enquadramento do problema de uma potência do corpo.

O corpo afetivo-performativo é então ligado ao poder em mais de uma visada - ele não só mostra o poder da puissance (a criativa capacidade ou o potencial para existência que permite multiplicar conexões com outros corpos), mas através desse mesmo potencial, ele pode em alguns momentos impactar relações de poder (pouvoir) em uma dimensão 
mais social ou institucional, mesmo se esse impacto está confinado ao filme e/ou à desorganização perceptual e afetiva do espectador (DEL RÍO, 2008, p.17).

E aqui nosso problema em torno dos engajamentos nos leva a estabelecer um elo de ligação entre a escritura do filme e as potências de agir que podem emergir desde o encontro afetivo entre corpos, no ato mesmo de ver uma imagem. Tentando indicar um tanto mais concretamente: se nos interessa muito de perto essa chave da performance, atrelada ao corpo fílmico, dizendo respeito a ele, e não apenas aos corpos na cena, é porque essa ideia nos possibilita falar de um engajamento afetivo do espectador que guarde uma possibilidade emancipatória, para além de uma continuidade teleológica entre filme e mundo. O corpo do espectador não pode ser uma representação nem uma abstração, mas também se performa na singularidade do encontro. Se existe performance e mútua afetação, é porque cada contágio também impõe um percurso dinâmico de um corpo pelas formas e forças de outro corpo. E essas travessias, conforme Del Río nos instiga a crer, pode se revestir de uma dimensão social e coletiva, permeada por singularidades. Nossa pergunta, lançada no início, a respeito dos engajamentos do filme com o presente e a vida coletiva, de um lado, e do corpo fílmico com o corpo do espectador, de outro, se reveste agora de uma aproximação interessada em saber como pode um filme compor uma comunidade com o espectador, ao traçar com o mundo uma comunidade de insurgência.

\section{Máquina e formas de insurgência}

Uma visita a um prédio em construção, nos moldes de uma aparentemente apaziguada contemplação de uma futura vida familiar em suítes espaçosas e varandas gourmets, transforma-se em um ato de violência sexual cometido por Gustavo e Bruno, os dois personagens centrais de Nova Dubai, ao corretor de imóveis que conduz o tour pelos cômodos de um novo apartamento, forçado a fazer sexo oral nos dois rapazes. A cena é filmada inicialmente com toda uma construção mais controlada da decupagem, que reserva para um momento muito particular o contracampo emblemático desse filme todo, talvez a evidenciar o grande inimigo em jogo aqui. Enquanto os três personagens estão juntos a uma janela, a olhar um fora-de-campo, o corretor faz o elogio da vista para a paisagem de prédios em ascensão, no projeto imobiliário de cidade vertical, a ser 
permeada por grandes torres de escritórios - justo a Nova Dubai, que dá título ao filme, o projeto empresarial de futuro para uma cidade concebida como modelo de gestão. É nesse instante preciso que a montagem nos joga para esse terreno que, aos olhos do mercado, é apenas espaço a ser preenchido por edifícios, uma paisagem ampla que tem ao fundo outros blocos de concreto de envergadura considerável e de reluzentes vidros. A montagem se insere aqui como operador dialético, para evidenciar mesmo uma estrutura social de contradição no mundo vivido. Mas depois desse diagnóstico crítico de uma problemática, o gesto do filme vai passar para um ataque direto ao inimigo, personalizado aqui pelo sujeito que tenta vender a promessa do sonho e que passa a ser violentado sexualmente. Nesse ataque, passamos a uma tessitura fílmica que remete à estilística já recorrente ao longo do filme, com planos próximos à ação sexual e com uma experiência de duração e de montagem que tenta reforçar a inscrição verdadeira dos choques entre os corpos na densidade do quadro. Nova Dubai não é um filme de sutilezas, mas um cinema que solicita o engajamento do espectador de modo bastante agressivo e direto. É ao mesmo tempo, um cinema que se engaja no presente, por meio de alguns gestos intensivos de combate corporal.

E esse embate entre corpo fílmico e corpo do espectador tem a singularidade do caminho que apontamos no início, o de apropriação, pelos artifícios formais do filme, dos campos discursivos mais ligados à tradição de uma "promessa de real", expressão já utilizada por Mariana Baltar (2014). Em um denominador comum entre documentário e pornografia, haveria uma estratégia semelhante de partir para o contato com o corpo do espectador, pela "mobilização de desejos e saberes sustentados a partir de uma promessa de real, que se cumpre pela visibilidade das performances dos corpos nas telas (performances de fala e performances de sexo)" (BALTAR, 2014, p.2). Nesse sentido, é o real que entra aqui como efeito de atração ${ }^{3}$, na medida em que ele se estrutura como parte fundamental do fascínio que a máquina desperta, da sua possibilidade de inscrever uma luz do mundo na superfície sensível do artefato. O mecanismo mesmo do aparelho passa a se evidenciar pelo efeito de realidade, ainda que esse efeito não cesse de se colocar também como parte de um jogo de ilusão. Essa tensão constante entre a encenação e o sexo real se precipita para a tessitura de Nova Dubai, justo como modo de apelar para um envolvimento afetivo do espectador, de convocá-lo pela via da crença na performance

3 Ensaiamos essa noção, inspirados em Jane Gaines. Ver o texto dela a esse respeito em: GAINES, Jane M. Everyday Strangeness: Robert Ripley's International Oddities as Documentary Attractions. In: New Literary History, vol. 33, 2002, pages 781-801. 
inscrita no quadro. É esse curioso interpolamento entre a intensificação da atração e o jogo com o real que entra na efetuação mesma do dispositivo desse filme: especialmente na sequência em questão, em que se expõe um ato violento de ataque, é o próprio gesto de filmar de modo tão próximo e participativo que contribui para as relações afetivas com o corpo do espectador. As ações fílmicas, digamos assim, são embates intensos com o mundo e com o olhar, porque a própria câmera se implica de modo explícito nas performances. É nesse sentido, que a própria máquina também performa, na medida em que a câmera se torna parte constituinte dos combates.

O jogo complexo que Nova Dubai traça com o pornô e com a promessa de real é decisivo para estabelecer mesmo um elemento de crença diante do ato disponibilizado ao olhar do espectador. Há um pacto de ficção traçado na estrutura do filme, mas este é constantemente infiltrado e deslocado pelo modo de filmar o sexo em espaço público. Seguindo a trilha de Susanna Paasonen (2011), diríamos que o filme instala uma experiência de ressonância carnal com o espectador, ao estabelecer essas relações de contrabando com os recursos da pornografia. A atração é diretamente relacionada ao nível de autenticidade inscrita na cena, jogando ainda com os próprios "arquivos somáticos" (PAASONEN, 2011, p.203) do espectador, convidado a reenviar à memória contida no próprio corpo daquilo que é constitutivo do encontro carnal. Na argumentação de Paasonen a respeito da pornografia online, é crucial a noção de que o espectador é agarrado [grabbed] pelo que vê na tela. Para além de um simples jogo de identificação e de vouyeurismo, paradigmas clássicos em muitos estudos sobre a noção de ponto de vista em vídeos pornográficos, Paasonen sugere esse deslocamento para o grab, que enseja outra maneira de se situar diante dos regimes espectatoriais na pornografia online. "O que agarra, ressoa: demanda atenção e tem o poder de mover e tocar quem está interessado naquilo. A agarrada [grab] pode ser experimentada como perturbadora, despertadora ou surpreendente. Dependendo da ressonância afetiva, os usuários podem virar as costas para as imagens ou se aproximar ainda mais para serem mobilizados e impressionados" (PAASONEN, 2011, p. 179).

Guardando as singularidades dos materiais estudados por Paasonen, interessa-nos aqui pensar a possibilidade de ressonância carnal e grab, advindos com as imagens de Nova Dubai, justo a partir dos recursos de infiltração da pornografia na tessitura fílmica. É preciso considerar que essas cenas de sexo público se inserem no projeto mesmo de colocar em crise um modo de organização do espaço urbano. A tática é, então, dialogar, de 
um lado, com a máquina pornográfica geradora de ressonância carnal e de crença no real, para tensionar, de outro, a máquina social organizadora dos fluxos no urbano, das fronteiras, das normatividades. Se propomos falar aqui de uma figura de insurgência tanto em Nova Dubai quanto em Branco sai preto fica, filmes em investigação de ataques frontais a determinadas lógicas de conformação das potências do corpo, essa figura tem, no caso de Nova Dubai, a modulação rumo a uma manipulação do real contra ele mesmo. O gesto é aqui cheio de camadas. O sexo em espaço público se investe da urgência de uma intervenção em ato, como se fosse preciso transmitir para a cena o risco e a experiência da própria performance no lugar aberto, fora das quatro paredes. Enquanto vemos a sucessão de inserts com os closes em penetrações, paus e bundas, a montagem não cessa de salientar os olhares preocupados dirigidos ao fora-de-campo, convocando uma atmosfera de perigo e de clandestinidade para a ação mesma que se desenvolve diante da câmera. A insurgência preparada, nesse inconformado confronto com o espaço urbano, ganha duração e tessitura de um ato real no corpo da cidade, inscrito no artefato cinematográfico e engajando o corpo do espectador no calor dessa operação de desvio desejante. A mobilização sensorial dos afetos rumo a uma outra partilha de cidade se trama no paradoxal jogo entre o trabalho de forjar a cena e o de maquinar um mundo performado com efeitos de realidade.

Aqui é preciso considerar ainda que estamos diante de uma ocupação do urbano feita no franco questionamento da heteronormatividade, num esquema de jogo entre amigos que usam táticas de corpo e de desejo para reconfigurar lugares da cidade. Em termos de Michel de Certeau (1998), se o lugar é regido pela lei do próprio, marcado pela estabilidade e pela regulagem das posições, a transformação de lugar em espaço passa pela variação das práticas nele inseridas, pela introdução de outras velocidades e tempos. "Diversamente do lugar, [o espaço] não tem portanto nem a univocidade nem a estabilidade de um "próprio'” (1998, p.202). As práticas de espaço são, nesse sentido, radicalmente experimentadas pela experiência sexual e tensionadora das normas, que explodem qualquer univocidade e estabilidade, a começar pelas prescrições mesmas no que se refere à sexualidade. As leis dos próprios, típicas dos lugares, são torcidas no sentido mesmo de uma complicação das formas de expressão do desejo, como se pudéssemos conjugar práticas de espaço e de corpo, manejadas em conjunto, no franco ataque às regulagens do desejo e do urbano. O engajamento de Nova Dubai no mundo vivido articula, portanto, um duplo movimento: há tensão com uma cidade atravessada 
pela especulação imobiliária, no mesmo passo em que são postos em crise os esquemas reguladores da sexualidade.

A enunciação de um sonho por parte de Bruno, acompanhada de um conjunto de imagens em Super-8, condensa ainda outras camadas que vão atravessando a escritura. Porque além dessas cenas de sexo em espaço público, há também uma alternância por dois personagens: um que, sempre deitado na cama, narra os desejos de suicídio, e outro que, em sequências nas quais o registro é mais marcado pelo artifício, abre algo como um portal para um arquivo de filmes de terror, cujas cenas são comentadas sempre em meio à paisagem em transformação pela construção civil. Essas duas outras camadas se reúnem no relato do sonho, porque se explicitam como parte de um só e mesmo projeto de constituir um mundo em que outras manifestações sensíveis sejam possíveis, um mundo em que todos esses personagens possam se reunir como uma gangue, para fabricar outro lugar de afetos, frente ao território de restrições. As imagens desse sonho inserem outra textura ao filme e outra modalidade de registro, marcando uma heterogeneidade em relação ao material predominante. No filme em Super-8, o caráter de mundo imaginado ganha destaque, como se fizesse parte de um porvir ainda não presente, porque ainda projetado e preparado.

Essa história contada por Bruno é bastante emblemática, sobretudo, porque ela enlaça, em alguma medida, os procedimentos dispersos em constelação pela montagem. A gangue já vinha efetivamente tocando o terror, se pudermos dizer assim, nesse outro cenário de terror, por isso não são à toa as constantes aparições do personagem que relata verbalmente os acontecimentos de filmes como Pânico, no qual uma das personagens surge enforcada pelo assassino mascarado. Que exista uma fundamental aproximação linguística entre terror e território, importante resgate que Mariana Souto (2013) vai buscar no pensamento da geografia, isso nos parece central para compreender a estratégia de insurgência em Nova Dubai. A autora toma uma questão tornada emblemática por JeanLouis Comolli (2008), ao se perguntar sobre os desafios de filmar o inimigo, e propõe a figura do terrorismo para articular alguns documentários brasileiros contemporâneos: Um lugar ao sol (Gabriel Mascaro, 2009), Vista Mar (Rúbia Mércia, Pedro Diógenes, Rodrigo Capistrano, Victor Furtado, Claugeane Costa, Henrique Leão, 2009) e Câmara Escura (Marcelo Pedroso, 2012). Ao se colocarem diante dos inimigos de classe, esses trabalhos engajam-se "numa relação de crítica, conflito ou confronto ataque" (SOUTO, 2013, p.293). 
Essa postura de confronto com a alteridade, conforme observa Souto, se insere num cenário de filmes brasileiros em que não parece à toa uma produção intensa tanto de ficções de terror quanto de documentários terroristas - e apostaríamos ter em Nova Dubai uma curiosa infiltração entre essas duas tendências. Para citarmos o procedimento de apenas uma dessas obras analisadas pela autora, destacaríamos uma que nos interessa em particular para nosso argumento, o curta Câmara Escura, de Marcelo Pedroso. Nesse trabalho, o realizador deixa na porta de casas de moradores de classes altas uma pequena caixa, na qual está guardada uma câmara filmadora. Ele interfona, foge apressadamente, e o filme será a reunião, na mesa de montagem, do conjunto de situações inusitadas disparadas por esse gesto, todas elas marcadas pelo medo dos moradores diante da encomenda recebida. "No filme, a câmera se torna artefato bélico, confundida com uma arma - um aparato de vigilância, um rastreador de localização, uma bomba" (SOUTO, 2013, p.296). Não será nossa intenção comentar mais de perto os desafios éticos dessa operação de Pedroso, mas interessa reter aqui a figura desse ato terrorista, a partir do qual a máquina cinematográfica integra um jogo de combate, como num gesto clandestino de guerrilha urbana. Uma câmera, guardemos isso, que se torna artefato bélico.

Essa passagem pelo terrorismo estético desse cinema brasileiro recente nos ajuda a retomar, finalmente, a bomba musical lançada em Brasília por Branco sai preto fica, com toda a sua força de artifício. Imaginação posta em pleno funcionamento, a trama não deixa de ser marcada pelo trauma do real, mas agora ela opera os contágios por meio de uma franca incorporação dos filmes de ficção científica, de uma possível agregação afetiva vinda da Sessão da Tarde ou de um Blade Runner que injeta o espírito pós-apocalíptico aos cenários noturnos da Ceilândia, esse país exterior, empurrado para fora, como já caracterizou César Guimarães (2014). Vingança de cinema: retomar o imaginário das ficções é a arma que os povos encontram aqui para forjar um ataque cinematográfico a geometrias, ordenações e projetos dos poderes. No cinema, essa misteriosa e mágica máquina de atrações, é possível constituir um abrigo fabular comum, para que as violências padecidas cotidianamente, e não apenas em um ponto específico do passado, possam encontrar uma medida de sobrevivência coletiva. Vingar é gesto de sobreviventes apesar de tudo.

No que concerne mais diretamente aos códigos da ficção científica, Alfredo Suppia (2017) já desenvolveu uma rica análise a respeito dos modos de apropriação elaborados pelo filme de Adirley Queirós diante da iconografia de "cenários decadentes e poluídos" 
(2017, p.8), contida em muito do universo desse gênero cinematográfico. Na tessitura de Branco sai preto fica, o autor chega ainda a enfatizar a situação fronteiriça emblemática do filme, que dialoga também com toda uma tradição tão cara a um filão de filmes de ficção científica - a dos borderlands science fiction films ${ }^{4}$. No caso singular do filme brasileiro, tratase, ainda segundo Suppia, de elaborar a fronteira, simultaneamente, como cenário, estratégia, tema e metáfora (2017, p.14).

Para os limites deste artigo, interessa-nos considerar que Branco sai preto fica dialoga com a possibilidade imaginativa aberta pela ficção científica, tanto literária quanto cinematográfica, para se lançar na relação com a experiência histórica e vivida concretamente pelos sujeitos sociais em cena. $O$ que nos instiga é esse gesto de apropriação, que produz uma política da ficção, elaborada em estreito laço com os mundos coletados do real, os testemunhos, as fotografias dos anos 1980, as vozes, os gestos e os rostos daqueles que experimentaram no corpo a repressão policial e, a partir do filme, passam a fabular, com engenhocas, papel, lápis, bunkers e bombas sonoras, toda uma possibilidade de reparação. Para além de reivindicar aqui uma referência direta, tomaríamos de empréstimo uma reflexão de Ursula K. Le Guin (1996), autora de literatura de ficção científica, que propõe toda uma teoria da ficção baseada na figura de uma bolsa. Trata-se aí de contrapor-se a modelos de narrativas organizados segundo a estrutura da lança, que aponta para um futuro certo e seguro: no lugar da lança, uma bolsa, que permite recolher, guardar, coletar. Dirá ela:

É um estranho realismo, mas trata-se de uma realidade estranha. Ficção científica propriamente concebida, como toda ficção séria, entretanto divertida, é uma maneira de tentar descrever o que de fato está acontecendo, o que as pessoas realmente fazem e sentem, como as pessoas se relacionam com todo o resto nessa vasta bolsa (LE GUIN, 1996, p.154).

4 Além do próprio artigo de Suppia, e para mais detalhes a respeito desse campo de filmes de ficção científica, remetemos ainda ao texto de Lysa Rivera, ao qual chegamos pelo texto de Suppia. Ver: RIVERA, Lysa. Future Histories and Cyborg Labor: Reading Borderlands Science Fiction after NAFTA. Science Fiction Studies, v. 39, n. 3, Science Fiction and Globalization, p. 415-436, nov. 2012. Ainda sobre a ficção científica no processo criativo de Branco sai preto fica, vale lembrar que Adirley Queirós chega a mencionar, recorrentemente, um livro de contos fundamental como inspiração, Crônicas marcianas, de Ray Bradbury. A título de exemplo, ver a esse respeito a seguinte entrevista com o realizador: SUPPIA, Alfredo; GOMES, Paula. Por um cinema infiltrado: entrevista com Adirley Queirós e Maurílio Martins a propósito de Branco Sai, Preto Fica (2014). Doc On-Line, n. 18, Interatividade e documentário, setembro de 2015. Disponível em: <http://www.doc.ubi.pt/18/entrevista_2.pdf>. 
Em Branco sai preto fica, a encenação e a montagem ressaltam, constantemente, o caráter de ficção desse mundo que tem, no entanto, uma sustentação muito grande nas experiências vividas. A ficção científica é feita aqui recolhendo pedaços de um território. Caminho inverso ao de Nova Dubai, aqui a máquina opera por intensificação do artifício, que paradoxalmente adensa a sensação daquilo que se vive nos corpos. Se estamos na cidade-satélite que sofre, na cena do urbano, uma efetiva segregação, cabe à cena fílmica exacerbar o sentimento de isolamento, na fábula dos passaportes que são necessários para permitir o deslocamento entre Ceilândia e Brasília. Se as periferias padecem, cotidianamente, das repressões policiais, aqui temos uma ronda noturna que decreta o toque de recolher, na missão de uma Polícia do Bem Estar Social, a controlar a ocupação das ruas. Esses elementos narrativos são tecidos em espaços de engenhocas improvisadas, fios soltos, portais temporais. A rádio-bunker de Marquim torna-se emblemática a esse respeito: ela se transfigura no lugar da fabricação da bomba, com sua localização subterrânea, seus aspectos clandestinos, como se esse lugar pudesse também se performar em cenário de ficção científica. Uma coluna de metal se transforma no objeto constantemente alimentado pelo personagem para aclimatar a bomba por vir. E nas paisagens descampadas, um grande contêiner adquire a atmosfera mágica, que o cinema torna possível, de transportar o agente Dimas Cravalanças por diversas camadas de tempo, para cumprir a tarefa de investigar os crimes cometidos pelo Estado contra as populações periféricas.

É preciso fabular, produzir a ficção, para que a insurgência e o engajamento no presente se produzam. Citando mais uma vez César Guimarães: "onde o real instalou o trauma e o mutismo, o imaginário retorna, reanimado pela ficção" (GUIMARÃES, 2014, p.198). É que a operação desse filme de Adirley Queirós encontra nas tramas e atmosferas da ficção o lugar estratégico para envolver afetivamente o espectador e para engajar os próprios atores na fabricação coletiva e na reelaboração do trauma. Como já disse Cláudia Mesquita (2015), é como se o documentário precisasse se transfigurar em ficção para fazer frente a uma outra grande ficção que o antecede, a própria idealização de Brasília. E assim, a autora chega a falar de uma contra-ficção em Branco sai preto fica, para enfatizar a apropriação que o documentário faz, não sem suspeitas, dos domínios da ficção científica, para gestar esse frontal ataque ao projeto do Estado (também um ataque terrorista, materializado enquanto máquina de cinema, como discutíamos a partir de Nova Dubai). De nossa parte, apostaríamos em distinguir duas ficções, conforme elas estejam apropriadas para a manutenção dos poderes ou pelas irrupções das insurgências. Diferentemente da 
ficção como simulacro, mundo ideal e projeto de cidade do futuro, encarnada por Brasília, poderíamos pensar numa outra operação ficcional, que já não diz mais respeito a fingir, mas a forjar mundos de dissentimentos. Ficção de novo estatuto que põe a primeira em crise. Não se trata de traçar uma mera oposição entre um mundo imaginário e um mundo real, mas justo de enfatizar uma alteração dos regimes do sensível e do apresentável, para atingir outras relações com os acontecimentos do nosso mundo histórico e das nossas vidas sociais.

Nesse gesto fílmico que desdobra já com largas braçadas a ideia de uma infiltração entre ficção e documentário, interessa perceber o quanto a ficção da vingança projetada por Adirley, Marquim e Sartana se afirma como geração de novas camadas ao mundo vivido, a partir do mergulho nos recursos dramatúrgicos do mundo encenado. Atores e personagens entram em um limiar indiscernível no qual já não importa onde começa um e termina o outro, porque é a própria cena que se produz em matéria de cinema $e$ de vida. Quando Marquim, na sequência de abertura, narra o trauma vivido no passado, esse lugar de vizinhança se sobressai, porque estamos diante de uma espécie de testemunho que incorpora toda uma potência dos recursos da dramaturgia e da montagem do cinema, e ainda da própria performance de Marquim. Esse testemunho singular toma por base a voz e o corpo do personagem em sua rádio, a retomar os acontecimentos no baile Quarentão. Sob o embalo de uma música, a montagem convoca também fotografias vernaculares que remontam à festa da época, enquanto Marquim segue narrando o episódio da invasão policial, modulando na voz os diálogos travados e controlando, no ato mesmo da transmissão radiofônica, a trilha sonora para o seu relato. Somos envolvidos por esse embalo sonoro, por essas imagens que se alternam entre o corpo de Marquim na cena e as fotografias reempregadas para remontar a um acontecimento, e finalmente por um grande estrondo que emerge ao final da sequência, após a subida dos sons de helicópteros. No lugar de recorrer a uma tradicional entrevista documental, a performance da fala e o testemunho do sujeito em cena são articulados como trabalho de drama: de um lado, pela reunião dos arquivos contidos nas imagens fixas, e de outro, pela construção sonora de uma ambiência para a cena que não está imediatamente visível, mas nos é sugerida. Gestualidade intensiva de um homem sentado em uma cadeira de rodas, a dramaturgia do corpo de Marquim mobiliza sensorialmente uma elaboração de cinema que toca tanto o presente quanto a experiência do passado, revivida e recriada na duração da própria exposição desses gestos. 
Atinge-se um conhecimento a respeito de uma situação social de perpetração de uma injustiça, ao mesmo tempo em que essa inteligibilidade atravessa e penetra o corpo, ritualiza-se como choque e catarse sensível. As formas do artifício em Branco sai preto fica se processam como um esforço para convocar a experiência coletiva dos sujeitos da Ceilândia e para possibilitar, no gesto de aparição deles na cena, a emergência de uma vontade de insurgência comum. A bomba sonora, arriscaríamos dizer, se constitui enquanto um bem comum, fabricado pelos sons coletivos e também irradiado da tela como grande explosão de sensações, a serem experimentadas na sua intensa alteridade. $\mathrm{O}$ recurso mesmo a um imaginário da ficção científica indica a apropriação coletiva dos códigos do cinema, para desmontar essa máquina de fabricar mundos e fazer com ela um outro projeto de experimentação da polis. O interesse do filme é muito mais o de tomar para si esses recursos formais e dobrá-los numa outra ficção, uma ficção constituinte, que engendre outra política do espaço e do tempo. Trata-se de tornar possível a emergência tanto de sujeitos não contados na distribuição de visibilidades estabelecida pelo biopoder, quanto a de uma cinema inaudito, em fissura também com certa configuração majoritária do campo do cinematográfico.

Da instigante demanda que Jane Gaines (1999) coloca para o documentário, a de que ele se engaje ativamente na produção de mudança social, podemos extrair potentes formulações no momento em que ela discute as táticas de guerrilha de vídeos em que a câmera torna-se arma e testemunha nas mãos de pessoas ordinárias. Estamos de volta àquela noção da câmera como artefato de confronto. Partindo da chave de uma mimese política, a autora propõe uma reorientação da discussão sobre o caráter mimético das imagens, distanciado de um puro transplante do mundo para a tela, e intimamente relacionado a um vínculo social com as histórias coletivas. Essa mimese política tem início com o corpo e diz respeito a relações entre corpos situados na tela e no público (GAINES, 1999, p.90). Trata-se de influenciar o presente e o futuro com os poderes mágicos da imagem em resposta às "brutalidades historicamente perpetradas contra pessoas ordinárias em nome do lucro" (1999, p.95). A autora nos oferece uma interessante construção verbal para pensar alguns documentários de resistência: ela toma alguns vídeos realizados no contexto de revoltas de comunidades negras em Los Angeles como uma poderosa ferramenta “to 'image back'” (1999, p.96), formulação que faz uma espécie de verbalização do substantivo "imagem" e que arriscaríamos traduzir como um "imagear de volta", para dizer da ação de uma imagem em seus gestos corpóreos de insurgência. Ainda que essas considerações de Gaines façam a opção teórica de sustentar o termo 
mimese, do qual preferimos nos distanciar, elas nos rendem muitos desdobramentos por enfatizar justo a luta sensual e o prazer visual que podem ser abrigados por uma imagem política (como nos pareceria mais interessante dizer, em lugar de "mimese política"). Especialmente quando se trata de argumentar em favor de uma "magia simpática", essa discussão da autora nos oferece uma interessante chave para pensar um cinema brasileiro recente que se dirige de modo bastante combativo para o mundo e para o corpo do espectador.

Para o documentário radical, uma noção de magia simpática nos permite lidar com o desejo de que as imagens possam mudar o mundo, de que os corpos na tela possam ter sua conexão concreta com corpos no espaço social, seja se os corpos em tela sejam vistos como se performassem o ideal ou como se encenassem o tabu. Finalmente, a noção do mundo e da tela como tendo relações "simpáticas", um com o outro, nos retira do reino de qualquer conexão mecânica, behaviorista, para colocar no reino da imprevisibilidade, abrindo a possibilidade de transformações miraculosas (GAINES, 1999, p.94).

Se aos pobres e negros foi delegado um país exterior, nas franjas de uma cidade barrada para aqueles que não têm passaporte, uma política da ficção pode se esgueirar com o cinema, para interpor uma cena de dissenso às cenas de esquadrinhamento policial. Branco sai preto fica solicita um engajamento, devolvendo ao espectador a intensificação, como artifício, daquilo que se configura no campo social. Esse contágio entre o corpo na tela e os corpos de uma comunidade de espectadores não se dá, como nos instiga Gaines, por mera conexão behaviorista, mas num terreno aberto de imponderabilidades. $\mathrm{O}$ que nos parece fundamental é que esse retorno do filme ao mundo é parte constituinte da sua estratégia, já que ele é feito como endereçamento muito direto para uma partilha coletiva, para projetar na vida coletiva saberes e sensações marcados nos corpos mutilados. É como se fôssemos interpelados por um comum fendido e de impossível reconciliação. Mas a recusa a qualquer apaziguamento não é a impossibilidade da partilha, ainda que ela se dê permeada por intervalos e distâncias. Uma comunidade pela imagem, engajada e mobilizada pelas formas da ficção, visibiliza-se, nesse filme de Adirley Queirós, como radicalidade da diferença. Expressão de um jogo de alteridades entre sujeitos, e entre filme e mundo, o bem comum constituído pela bomba sonora não é da ordem dos consensos, mas é cindido por experiências que se colocam em relação na sua absoluta heterogeneidade. Disso podemos perceber que a vida em comunidade não tem a ver com 
a formação de um Todo homogêneo, mas é um engajamento constante diante das fraturas experimentadas nas intermitências históricas e coletivas de nossa vida social.

\section{Notas finais: cinema e engajamento}

A questão de um cinema engajado, como apostamos, vem atravessando uma série de realizações do cinema brasileiro recente, desde filmes realizados às voltas com as urgências das manifestações de ruas em nossa experiência do presente, até filmes que se transformam em contundentes ataques, nos quais o artifício da máquina é posto como um projétil direcionado ao mundo, como no curta Em trânsito (Marcelo Pedroso, 2013) ou em Não estamos sonhando (Luiz Pretti, 2012) ${ }^{5}$, passando pelas vitais produções de realizadores indígenas, que constituem rituais com a câmera ou mesmo que se colocam em franco processo de resistência diante do massacre a que são submetidos, em meio às lutas pela terra. Essas formas díspares de engajamento no presente e no contato com o espectador abrem, a nosso ver, o cinema a um fora-dentro dele, demandando que pensemos a própria eficácia das escrituras numa rede de relações cartográficas que perpassam os acontecimentos de imagem e os modos pelos quais as invenções da máquina retornam à vida social. Pathos de um mundo, que se vê devolvido, como pathos, ao mundo em variação constante. Com o cotejamento dos singulares processos levados adiante por Branco sai preto fica e Nova Dubai, talvez possamos perceber o quanto uma imagem pode convocar, na sua íntima alteridade (dentro e fora coengendrados), imprevisíveis mobilizações afetivas, que concernem às experiências dos corpos em cena e à materialidade da máquina, mas também atravessam o outro diante da tela, desequlibrando o ver e fazendo surgir também sombras, lacunas e desvios nesse lugar constantemente inquieto do espectador.

5 Pensamos, especialmente, no recurso de Pedroso, ao criar uma cena na qual um boneco do antigo governador de Pernambuco, Eduardo Campos, tem sua cabeça cortada, na culminância de uma sucessão de artifícios de crítica aos modos de gestão do espaço urbano em Recife. E no caso do filme de Luiz Pretti, lembramos a utilização do gravador sonoro que é apontado para prédios em construção, fazendo-os explodir imaginariamente, por meio da vibração do quadro e do efeito sonoro de bombas que se precipitam no mundo. 


\section{Bibliografia}

BALTAR, Mariana. Entre afetos e excessos - respostas de engajamento sensóriosentimental no documentário brasileiro contemporâneo. In. REBECA. Revista Brasileira de Estudos de Cinema e Audiovisual, Volume 4, 2013.

Compós. v.17, n.3, set./dez. 2014.

. Real sex, real lives - excesso, desejo e as promessas do real. In. E-

CERTEAU, Michel de. A invenção do cotidiano, vol.1: artes de fazer. Petrópolis: Editora Vozes, 1998.

COMOLLI, Jean-Louis. Como filmar o inimigo? In: Ver e poder: a inocência perdida: cinema, televisão, ficção, documentário. Belo Horizonte: Editora UFMG, 2008, p. 123-134.

. Corps et cadre. Cinéma, éthique, politique. Lagrasse:

Verdier, 2012.

DEL RÍO, Elena. Deleuze and the cinemas of performance. Powers of affection. Edinburg: Edinburg University Press, 2008.

DELEUZE, Gilles e GUATTARI, Félix. O anti-Édipo: capitalismo e esquizofrenia 1. São Paulo, Ed. 34, 2010.

FURTADO, Beatriz; LIMA, Érico. Corpo, destruição e potência em Branco sai, preto fica. Revista Matrizes, v.10, nº 1, jan./abr. São Paulo, Brasil, 2016.

GAINES, Jane M. Everyday Strangeness: Robert Ripley's International Oddities as Documentary Attractions. In: New Literary History, vol. 33, 2002, pages 781-801.

. Political Mimesis. In: Collecting Visible Evidence. Eds. Gaines, J. M. and Renov, M. University of Minnesota Press, Minneapolis, 1999, pp. 84-102.

GUIMARÃES, César. Noite na Ceilândia. In: catálogo do forumdoc.bh $2014-18^{\circ}$ Festival do Filme Documentário e Etnográfico de Belo Horizonte. BH: Filmes de Quintal, 2014.

LE GUIN, Ursula K. The Carrier Bag Theory of Fiction. In: The Ecocriticism Reader: Landmarks in Literary Ecology. Edited by Cheryll Glotfelty and Harold Fromm. The University of Georgia Press. Athens, Georgia, p.149-154, 1996.

MESQUITA, Cláudia. Memória contra utopia: Branco sai preto fica (Adirley Queirós, 2014). In: XXIV Encontro Anual da Compós, 2015, Brasília. Anais do XXIV Encontro Anual da Compós, 2015. 
MIGLIORIN, Cezar. Figuras do engajamento: o cinema recente brasileiro. Devires, v. 2, p. 13-27, 2011.

PAASONEN, Susanna. Carnal Resonance - Affect and Online Pornography. 1a. ed. MIT Press, 2011.

RANCIÈRE, Jacques. O espectador emancipado. Lisboa, Orfeu Negro, 2010.

SOUTO, Mariana. Documentários terroristas? - inimigos de classe no cinema brasileiro contemporâneo. In: catálogo do forumdoc.bh 2013 - $17^{\circ}$ Festival do Filme Documentário e Etnográfico de Belo Horizonte. BH: Filmes de Quintal, 2013.

SUPPIA, Alfredo. Acesso negado: circuit bending, borderlands science fiction e lo-fi sci-fi em Branco Sai, Preto Fica. Porto Alegre, v. 24, n. 1, janeiro, fevereiro, março e abril de 2017. 